CIRR XXII 175) 2016, 9-38

ISSN 1848-5782

UDC 656.6:347.79.061.1EU

DOI 10.1515/cirr-2016-0001

\title{
The EU's Maritime Security Strategy: a Neo-Medieval Perspective on the Limits of Soft Security?
}

Brendan Flynn

\section{Abstract}

This paper offers a critical interpretation of the EU's recent Maritime Security Strategy (MSS) of 2014, making distinctions between hard and soft conceptions of maritime security. The theoretical approach employed invokes the 'EU as neo-medieval empire' (Bull 1977: 254-255; Rennger 2006; Zielonka 2006). By this account, the main objectives of EU maritime strategy are stability and encouragement of globalised maritime trade flows to be achieved using the classic instruments of 'soft maritime security'. While replete with great possibilities, the EU's maritime security strategy is likely to be a relatively weak maritime security regime, which suffers from a number of important limits.

KEY WORDS:

European Union, maritime security strategy, hard and soft conceptions 


\section{( Maritime Security - Hard and Soft Varieties?}

Since the declaration of its Marine Security Strategy (MSS) in 2014, the EU has loudly proclaimed itself to be a global player in maritime security. The subject of this paper is whether, in fact, it is likely to become a credible one. The exact question here is: What type of maritime security actor is the EU? Not: Why or how can we explain the emergence of the EU's maritime security dimension? Those latter questions have already been well addressed by other scholars (Germond 2015; Riddervold 2011, 2015). Moreover, to explain how the MSS came about, one could add references to the literature that draw on EU bureaucratic politics (Dijkstra 2009; Hilsman 1987; Trondal et al. 2015; Vanhoonacker et al. 2010) and policy entrepreneurship (David 2015), especially from key elites in national, Council, and Commission institutional settings, and on the 'ground' (Arnold 2015). The issue of there being limits to the EU's MSS is also explored here, especially because what is in question is a 'soft' maritime security regime. These suggested limits to the MSS are based on the literature on neomedievalism.

The paper is structured in three main sections. First, a discussion on the distinction between hard and soft maritime security is offered, together with an analysis of how the MSS text clearly positions itself at the 'soft' end of that spectrum. A second section moves from analysis of policy documents to evaluating a series of puzzles concerning the recent history of the EU's role in maritime security. These puzzles relate to the character of the EU as a security actor but also to how understanding the EU's role in maritime security fits poorly within the dominant international relations' (IR) theoretical approaches. Third, the paper presents the distinctive neomedieval (IR) approach, explaining how it can be applied to the MSS. In a final extended discussion and conclusion, the neo-medieval approach is employed to draw out a number of limits that the EU faces as it attempts to become a significant maritime security actor.

\section{Maritime Security - Hard and Soft?}

Any definition of 'maritime security' ought surely to be wide enough to 
reflect Bueger's (2015) matrix, which stresses the sheer diversity of topics that can fall under the heading. However, a spectrum of marine security challenges and activities between 'soft' and 'hard' variants of maritime security (Rao 2010) is emphasised here. This echoes Colin Gray's (2011) Hard/Soft power distinction.'

The essence of hard maritime security is the willingness to use force at sea, or from the sea, to achieve desired political effects, whether for a nation state or an alliance (naval), such as NATO. It is about naval war fighting and defence of sea lanes, maritime interests and marine spatial hegemony. Soft maritime security is not just 'everything else', but it surely involves a focus on normative rather than military force, and on co-operation and consent rather than conflict. It could be called, in old-fashioned language, 'constabulary' activities at sea with the chief characteristic that force will not likely be employed, or if it is, such force will be limited and normatively constrained. It is quite unlike naval war fighting. Of course, there is a grey area between 'soft' and 'hard'. Thus anti-piracy operations off Somalia have included some 'kinetic' features in what is otherwise a maritime policing mission. Moreover, some soft powers can be surprisingly 'hard'. The EU has, for example, quite hard 'economic' powers, should it choose to use them, engaging in trade wars, sanctions, and extra-territorial regulatory initiatives.

There are also ontological distinctions between 'hard and soft' maritime security. For example, hard maritime security threats usually relate to more objective, real, material maritime interests of states, alliances, or organised non-state actors. Examples of such include littoral territory or access to sea lanes, fishing grounds, or seabed mineral wealth. By way of contrast, soft maritime security issues are likely to be socially constructed, 'ideational' or 'securitised' issues, to which elites or electorates seek responses from navies, coastguards, and even perhaps from NGOs and civic society actors. Russia's launching an amphibious assault on Mariupol (Ukraine) might be a good example of a hard maritime security threat, whereas framing mass irregular migrants as 'climate change victims' represents the 'softer' end of the maritime security spectrum.

Gray clarifies the distinction as follows: 'The former, hard power, is achieved through military threat or use, and by means of economic menace or reward. The latter, soft power, is the ability to have influence by co-opting others to share some of one's values and, as a consequence, to share some key elements on one's agenda for international order and security' (Grey 2011: V). See also Lindley-French (2004). 
A systematic discourse analysis of the recent EU MSS or its action plan is not offered here. Nonetheless, as a document, it is obviously replete with language that fits the softer end of the maritime security spectrum. There is much less of the hard security talk we might expect from organisations such as NATO. For example, the MSS text contrasts sharply with NATO's statement on maritime strategy (2011), which has an entire section devoted to 'deterrence and collective defence'. ${ }^{2}$ One can also contrast the EU MSS with the recent British National Strategy for Maritime Security (NSMS) (HMG 2014). While this document has a great number of references to international law, upholding norms and keeping maritime trade free, it also has a very clear statement that the purpose of the UK's NSMS is to further British national interests. Moreover, it uses a coherent risks assessment, which notably creates a hierarchy of risks to be prioritised, with marine terrorism near the top.

As a document, the EU MSS can be described as somewhat rambling, reflecting classic liberal security rhetoric, and certainly does not offer any clear strategic choices. It purports to identify common maritime security interests for the EU, but these are widely pitched. For example, they include: 'the protection of economic interests, including the safeguarding of maritime energy resources' alongside 'the protection of the environment and the management of the impact of climate change in maritime areas and coastal regions, as well as the conservation and sustainable use of biodiversity to avoid future security risks' (Council 2014: 7). The fact that extracting oil at sea may be in profound conflict with climate change concerns is entirely glossed over. In short, it is a rather typical 'curate's egg' of an EU document-by-committee.

It is certainly not an exercise in naval strategy for brute hegemony. The text states EU maritime actions are to be 'based on the EU's founding values of human rights, freedom and democracy' and 'Maritime security is understood as a state of affairs of the global maritime domain, in which international law and national law are enforced, freedom of navigation is guaranteed and citizens, infrastructure, transport, the environment and marine resources are protected' (Council 2014: 3). The only hegemony sought here is that of liberal norms. Moreover, while protecting EU maritime, borders are mentioned; this is not against hostile states or terrorists but 
'in order to prevent and counter cross-border illegal activities' (Council 2014: 7). Somewhat confusingly, the document shortly afterwards shifts to language closer to hard security. It states the EU must attend to 'threats to the security of European citizens and to economic interests at sea following acts of external aggression including those related to maritime disputes, threats to Member States' sovereign rights or armed conflicts' (Council 2014: 7). Terrorism and $\mathrm{CBRN}^{3}$ risks are included on the same page as ' 'llegal and unregulated archaeological research and pillage of archaeological objects' (Council 2014: 8). The EU MSS is supposed to be about managing all of these diverse issues and more.

There are only oblique references to the deployment of 'harder security' assets in the EU MSS. Consider, for example, the following statements: 'Member States' Armed Forces should play a strategic role at sea and from the sea and provide global reach, flexibility and access that enable the EU and its Member States to contribute to the full spectrum of maritime responsibilities. Their sustained presence needs to support freedom of navigation and contributes to good governance by deterring, preventing and countering unlawful and illicit activities within the global maritime domain' (Council 2014: 10). There is also reference made to NATO, but an ambiguous formula is used: "the EU should act autonomously and with international partners. Special attention should be given to the development of partnerships with international organisations. The Union's capacity to cooperate with the UN, NATO, regional partners like the African Union or ASEAN, as well as multilateral civil cooperation platforms, has a direct impact on its ability to safeguard its interests and to strengthen regional and international maritime security. In the context of crisis management, EU and NATO engagement in the maritime domain should remain complementary and coordinated, in accordance with the agreed framework of the partnership between the two organisations' (2014: 10).

In a way, this text is clear in what it doesn't say. It is not stating that there will be an EU maritime security capability developed apart from NATO. Nonetheless, a capability to act autonomously is implied by textual references to 'full spectrum' or 'armed forces', which suggests the possibility of the use of force at sea in the EU's name. However, the rest of the MSS is a rhetorical tour de force of liberal, soft security approaches.

3 A military acronym for threats, training or technology of a Chemical, Biological, Radiological or Nuclear type. 


\section{(2) The EU as a 'Soft' Maritime Security Actor: Five Puzzles}

In this section, the focus moves away from the text of the MSS (what the EU says) to a potted history of EU efforts on maritime security (what the EU has actually done). Once again, the core observation is that soft maritime security provision dominates the EU's efforts. The EU as an actor is not a naval war-fighting alliance, whereas NATO ostensibly is. Rather than repeat the story of how the EU became involved in maritime security, trends to date are presented as a series of 'puzzles' for academic research.

\section{The puzzle of timing}

That the EU's entry into the marketplace of maritime security institutions is relatively new must be emphasised. It also suggests that the EU as a maritime security actor is unproven. Explicitly, EU naval missions date back to Operation Atalanta in 2008, so they are not even 10 years old. Why should we then assume the EU will be deploying naval missions in its name some 10 years from now, or that the EU will even be an important maritime security actor by then?

Why did we have to wait until 2008 for a dedicated EU naval mission to emerge? This is puzzling, because we know the usual 'Cold War' excuse was long gone by then. One might blame ' $9 / 11$ ' and how it derailed things by shifting agendas towards terrorism and counter-insurgency on land. Yet, we know that at St. Malo in 1998 there was a high-level understanding, at least between the French and British, that EU-led military operations could be acceptable and that they would collaborate to ensure an 'autonomous capacity to manage international crises'. The intention was for an EU military capability, including naval assets, that would be complementary to NATO but, if needed, could also operate outside NATO structures (Catalano 2015: 119-120).

An enormous amount of speculation was generated by the creation of an EU 'force catalogue' for the Helsinki Headline Goals and naval forces featured strongly in that paper exercise. The controversy surrounding the creation of an EU Rapid Reaction Force came mostly to nothing of real institutional value (Whitman and Wolf 2012: 12). The much-truncated 
EU Battle-groups structures that eventually emerged in its wake have never been used in any significant way, even though there have been occasions when they could have been deployed, including with naval and amphibious elements. Using them was briefly considered during the Libyan crisis (2011), but a lack of political agreement among the EU member states and the fact that such a mission would have been 'kinetic' from the outset all conspired to shelve the idea in preference to intervening using NATO (HoL 2012: at p. 66). The lesson here is stark: the EU's readiness to use, or even allocate, naval capabilities at the 'harder' end of the spectrum remains still unproven after years of speculation.

Alongside EUNAVFOR, which is lavished with publicity and is a creature of the Council and intergovernmental bargaining, we should note how the European Commission has steadily pushed its own way into maritime security. Central here are the EU CRIMSON projects ${ }^{4}$, which access funding under the DG for Development and Co-operation. However, such projects have only emerged since 2009. Labelled the Critical Maritime Routes Programme and launched at the height of the piracy crisis off the coast of Somalia, this initiative has had a relatively small budget of $€ 16 \mathrm{~m}$. Nonetheless, it has managed to develop specific projects for each of the main trade routes where piracy is a problem (Somalia/Western Indian Ocean, South East Asia/Straits of Malacca and now the Gulf of Guinea). Alongside these measures, there is also the obviously normative 'Comprehensive Approach' to EU security, which has been centre stage of efforts like EUCAP NESTOR. This approach blends a judicious mix of development, rights, democracy promotion, and local institutional capacity building. We can leave aside for now to what extent such policies are truly effective. It is enough to note for our purposes here that once again this is material, which is almost a cliché, of soft security approaches.

\section{The puzzle of institutional complexity}

Second, there is a puzzle concerning the fact that the EU, as a provider of maritime security, faces Janus-like dynamics of institutional competition and co-operation, often simultaneously. The focus for competition and

4 See: http://wnw.europarl.europa.eu/meetdocs/2014_2019/documents/sede/dv/sede160315criticalmaritimeroutesprogr_ J sede160315criticalmaritimeroutesprogr_en.pdf and http://ec.europa.eu/transport/modes/maritime/events/doc/2009_01_21_ piracy/maritime_routes.pdf 
co-operation is not just towards NATO or even UN-brokered naval task forces. The EU must also co-operate and/or compete with unilateral national actions at sea, with ad hoc coalitions of the willing, and there are various alternative multilateral European organizations for naval matters, notably EUROMARFOR (EMF).

This distinctive naval organization can be considered an evolutionary fossil from the mid 1990s, when the EU and the WEU were locked in an institutional courtship dance that ended with the eventual dissolution of the WEU and its merger into the EU (Bailes and Messervy-Whiting 2011). However, the EMF lives on having some organisational identity within Operation Atalanta and offering what it terms a 'non-standing but prestructured force'. ${ }^{5}$ To be clear here, such a capability is not an EU standing naval group, but in reality, a 'Club Med', which combines French, Spanish, Portuguese, Italian, Greek, and importantly, also Turkish naval forces. It sits, Matryoshka doll-like, within both NATO and EU naval structures (Marquina 1998: 239). There is even a bilateral Franco-German Naval force, which remains partially active6, although what exactly it might realistically do by itself is puzzling, except as a mechanism to keep warm Franco-German diplomatic relations.

The reality of European maritime security is then a confusing institutional complexity. ${ }^{7}$ There is no necessary reason why one organization above another (or indeed several at the same time) cannot respond to any maritime contingency. Why one would turn to the EU, among other possible institutional actors, is therefore an ongoing question that diplomats and decision-makers will ask. The EU is far from the most obvious institution in the event of an emerging maritime security crisis, even if we can acknowledge its rise in this area.

Yet, that rise is recent. It is important not to forget that before Operation Atalanta there were several ad hoc European missions under UN Mandates, but these were not EU-led naval interventions. For example, the Italian Navy led a coalition of the willing in Operation Alba of 1997 (Perlmutter 1998: 207), which combined a de facto naval blockade to

5 See: http://www.euromarfor.org/

6 See: http://www.defense.gouv.fr/marine/a-la-une/spontex-13-activation-de-la-force-navale-franco-allemande

7 Multilateralism or 'differentiated integration' are the more recognised terms for this. 
push back refugees, augmented by land forces. Its success was mixed, especially at sea, where the Italian Navy became mired in controversy after a collision with a migrant boat led to large-scale loss of life. In the late 1980s, the WEU also took responsibility for a minesweeping operation in the Persian Gulf, which again was a non-EU operation. Given the WEU's de facto merger into the EU, one assumes that such a mission today would be either given to the EU or potentially to NATO.

Also instructive is the example of naval peacekeeping off the coast of Lebanon in 2006, led by the German Navy. This mission was hastily put together in the context of an Israeli withdrawal from Southern Lebanon. However, this Combined Task Force 448 did not involve an EU dimension, there being instead a partial activation of the European Maritime Force (EUROMARFOR) to support the UNIFIL mandate. Once again, before the UN-mandated and German-led naval force arrived, the Italian Navy unilaterally provided an 'Interim Maritime Task Force' to cover Israeli naval withdrawal and help the Lebanese government before UNIFIL naval peacekeepers arrived (Marta 2008: 3). Today, that mission remains ongoing but with the participation and leadership of many non-EU navies, notably that of Brazil. ${ }^{8}$

The salience of nation state navies doing the operational heavy lifting here, along with ubiquitous ad hoc structures, should be obvious, rather than any well-developed and distinctive EU naval capability. Moreover, the outcomes of such soft maritime security operations are not immune to controversy. If the purpose of that operation was to give diplomatic cover for Israel to withdraw from its occupation of Southern Lebanon, then it can be judged a success. However, the objective of stopping Hezbollah's smuggling of heavy weapons (rockets) via ships has apparently been much less successful. It is possible that Hezbollah has continued smuggling weapons via the sea route after 2006, although many land routes are also available. ${ }^{?}$

What can we say about this institutional complexity? One lesson appears to be that the EU cannot assume it will always be the predominant nor

8 See: http://unifil.unmissions.org/Default.aspx?tabid=11584

9 For Israeli perspectives, see: https://www.idfblog.com/hezbollah/2013/11/04/4-years-ago-idf-stopped-hezbollahslargest-ever-weapons-shipment-iran/ and https://idfspokesperson.wordpress.com/201 1/07/19/list-of-attempts-byterrorist-organizations-to-smuggle-weapons-via-the-sea/ 
distinctively European maritime security actor at sea. In fact, operational choices for policy-makers are much more complex than a simplistic binary preference for either an EU or a NATO mission. A variety of institutional templates is available in emergencies, not least, old-fashioned, unilateral actions by national navies and ad hoc coalitions of the willing. It is easy to forget that the success of operation Atalanta has to be shared with parallel efforts by NATO's operation Ocean Shield and the US-led Task Force 151. Russia, China and a host of capable Asian navies (Malaysia, South Korea, Singapore) have all played important roles there, not to mention private security actors, such as ship guards, consultants, and shipowners. Moreover, it should be noted that NATO naval forces could easily compete or complement the EU to deliver naval constabulary security at the 'softer' end of the spectrum. They did so very effectively during the early stages of the naval blockade during the Yugoslavia civil war. ${ }^{10}$ So the puzzle here is: what does the EU uniquely offer for maritime security that other institutions, like NATO, don't?

\section{The puzzle of lethal force}

Third, there is a puzzle over why the EU to date has engaged in only very limited use of force at sea, certainly less than has been encountered by EU military missions on land, where, for example, the EU now seems in Mali to be engaged in 'counter-insurgency by proxy' (Skeppström et al. 2015). It is true that in 2012 at least one dramatic raid was launched by EUNAVFOR elements on beached pirate skiffs. There have been other encounters at sea where force has been used, but most of these have been smallscale incidents. Interestingly, the exact composition and nationality of the elements used in the beach raid of May 2012 have been kept confidential (to prevent harm to hostages of the same nationality). Thus, responsibility for the operations was given to 'EU forces' rather than specific national contingents. If things had gone horribly wrong (say, children killed) to whom would responsibility have been attributed - EU diplomats or some luckless national contingent and chain-of-command 'responsibility'?

By way of contrast with these limited violent incidents, some national navies, such as the British or French, have been recently involved in quite intensive

10 NATO also got drawn into the Yugoslavia crisis with Operation Maritime Monitor in July to November 1992, which became operation Maritime Guard until 1993, and then it transferred to WEU 'Ownership' as Operation Sharp Guard in what was a merger at sea of two different naval operational strands. 
naval warfare in the second Gulf War (2003) or the Libya intervention of 2011. They have been sinking 'enemy vessels', conducting amphibious raids and landings (Wollert 2013). EU maritime security forces have done nothing like this, nor do they seem likely to do so any time soon. The most recent EU Operation Sophia (2015, ongoing) was initially in its concept of operations drafted as a naval mission that would in stages progressively become more 'kinetic', up to and including military actions to destroy people-trafficking boats, possibly via amphibious or naval special forces raids. The actual reality is that Operation Sophia never received political support for such a use of force, both at the UN level but also from the EU's member states. In October 2015, when a UN mandate in Resolution 2240 was finally reached, after much Russian and Chinese delay, this mandate carefully limited the use of force to constabulary-type actions. " Moreover, EU naval operations within Libyan territorial waters (12 nautical miles) were expressly prohibited. The effect was to force this EU mission into being a much 'softer' intervention than what was originally planned.

\section{The puzzle of the "EUness" of EU maritime security after Brexit}

Fourth, there is a puzzle over the 'EUness' of EU maritime security, which is not entirely obvious. Some non-EU states are quite important players in the delivery of EU maritime security. Plucky little Iceland has made an amazing contribution, for its size and fiscal health, to the ongoing FRONTEX-organised rescue missions for migrants off Libya in 2015. Norway has participated in EUNAVFOR missions as early as $2009^{12}$, sending a frigate. Ukraine also sent a frigate in 2014, after it previously did a stint with NATO's operation 'Ocean Shield'. For obvious reasons, that ship is now back home, facing threats much more grave than Somali pirates. Switzerland sent troops to coordinate food shipments ${ }^{13}$, and Serbia has sent vessel-protection troops as part of Operation Atalanta. More recently, the Columbian Navy turned up for a stint on duty off Somalia with Operation Atalanta. ${ }^{14} \mathrm{New}$ Zealand briefly assigned her Orion patrol aircraft to EUNAVFOR in 2014 (after previously doing time with the US-led Combined Maritime Forces out of Bahrain). Moreover, the British and other EU states, including even

11 See: http://www.un.org/press/en/2015/sc12072.doc.htm, especially at points 8 and 10

12 See: http://www.eu-norway.org/newsl/frigate/\#.VfssGkVDpJM

13 See: http://eunavfor.eu/norway-and-switzerland-to-contribute-to-op-atalanta/

14 See: http://eunavfor.eu/operation-atalanta-ship-esps-meteoro-meets-colombian-warship-arc-7-de-agosto-at-sea/ 
the French, have not just deployed their navies to EUNAVFOR but also to Task Forces 150, 151, and NATO's Ocean Shield.

There is no exclusivity here and no effort to build a cohesive, specifically EU identity at sea. Instead, institutional promiscuity rules and pragmatic co-operation (quite rightly) holds sway. It seems NATO and EU forces off Somalia have worked very well with each other (Gebhard and Smith 2014), which begs the question: what exactly are the differences between the two entities? (Riddervold 2014). This precedent for NATO-EU co-operation is very important, following the shock of the Brexit referendum in June 2016 and the UK's apparently imminent exit from the EU. While there are unquestionable implications following this event for EU maritime security, it probably does not mean that the Royal Navy will never participate in EU maritime security missions.

British naval co-operation with the EU may be pragmatically framed within a joint NATO-EU template, although it is possible that the Brexit vote might push the Royal Navy's political masters towards a 'NATO-only' preference, somewhat like the position of Denmark (see below). However, considering that NATO also engages in similar soft security operations like the EU, often in parallel following the example of Operation Atalanta, the actual atsea operational outcomes of Brexit may be less obvious. It is worth noting that a Britain outside the EU could easily deploy its vessels and staff on any future EU maritime missions, relying on a Framework Participation Agreement (FPA) (Tardy 2014). One must reiterate how valuable and ubiquitous non-EU state participation in Operation Atalanta has been: the navies of Norway and even Columbia have all played a significant role.

However, Brexit would seem to imply that the Northwood command centre outside London will no longer be used as an EU command centre, as it is today (although its NATO significance will remain). Brexit seems to also imply future EU missions will also lose the leadership and experience of senior British officers, who have heretofore played a very visible and positive role. Moreover, as Tardy explains, FPAs have been not uncontroversial in practice, because states who use this expedient agree to participate in an EU security mission but on operational terms and conditions that they have only very limited ability to influence. They become operational followers at a late stage rather than pacesetters from the outset (Tardy 
2014: 4). Without the Royal Navy, any distinctively EU maritime operations will revolve around the increasing importance of not just the French Navy (which has always been central) but especially the participation of the German, Spanish, Dutch, and Italians, who now become simply more important to any EU mission success, precisely because the British are unlikely to be part of future missions or more marginal in their role.

In fact, a future British reluctance to participate in EU maritime security forays will be far from unique or peculiar. The case of Denmark is well known. Because of their Maastricht Treaty-era opt outs from EU security policies, Denmark pushes its impressive ability for anti-piracy missions exclusively through NATO structures. The same type of 'NATO first' logic applies to Turkey, although one should note their formal participation in the EMF, which leaves open the possibility for future non-NATO and nonEU types of missions at sea involving Turkey and several EU states. The orientation of recent Turkish governments has been to let slide a serious bid for membership of the EU, yet EU membership suddenly returned on the agenda in 2015 as part of the EU's desire to engage with Turkey on the refugee crisis and the Syrian civil war. Thus, Turkey's orientation towards an evolving EU maritime security role is likely to evolve, but for now, it seems safe to assume that Turkey's maritime capabilities will continue to be framed within either a unilateral or a NATO orientation.

The case of Ireland towards EU maritime security is less well known. While Ireland has deployed land forces on many EU missions, it has only sent naval officers as observers to Northwood in relation to Operation Atalanta. One reason why no Irish ships have been deployed to anti-piracy missions may be simply due to budgetary restrictions, however, the failure to secure a UN mandate for the mission until October 2015 was also a serious set-back, because domestic Irish law requires such for participation. However, Ireland deployed patrol vessels in 2015 and again in 2016 to the Mediterranean refugee crisis. However, the Irish authorities preferred a simpler bilateral diplomatic and legal agreement with the Italian Navy rather than getting mired in EU/Frontex bureaucracy. The result is that the Irish vessel operates alongside Italian and EU naval forces, following UNCLOS norms for rescue at sea, and remains formally outside the EU's operational control and chain of command. Such details should remind us that when we see maritime security operations labelled 'EU', we should ask if they are really such, or 
are they expedient coalitions of the willing of (mostly) European states, just not operating within a formal NATO or other such structure?

\section{The puzzle of theoretical interpretation}

Fifth, IR theories rear their ugly heads. Realists of different stripes and hues would, doubtless, find little difficulty explaining the EU's foray into maritime security as basically the development of insurance capabilities to allow European powers to engage in missions and face threats without relying on NATO and, therefore, US hegemony. One could understand it all as some type of 'internal balancing' within the European western block against America dominance (Kluth and Pilegaard 2011; Riddervold 2014; Rynning 2011). The logic of a 'back-up' naval force, formally distinct from NATO but informally co-operative with NATO naval structures, has a long pedigree. It was foreseen as a contingency for operations focused on spill overs from the Algerian conflict in the 1990s (fearing the Islamists might win) or as eventually happened in the case of Albania, a complete state collapse in 1997 leading to mass, uncontrolled migration at sea, a crisis that prefigures the current humanitarian disaster associated with Libya and Syria. French and British frustration with the US during the Yugoslavia wars also played a part in what we might term the 'St. Malo logic' of being 'close to NATO but if need be, also capable of operating outside NATO'.

In fairness to the Americans, the really 'awkward' countries inside NATO meetings today are likely to be Germany (still squeamish on the use of force, as seen in Libya 2011) or Turkey (in her neo-Ottomanist mode, unhappy with interventions that offend her geopolitical interests, such as various parts of the Balkans and today, Libya, or Syria). However, the puzzle here is, if the French and British foremost have invested in a distinctive EU security capability as insurance against NATO deadlock, then why have they stopped short of giving it a full spectrum of capabilities between soft and hard security measures?

The actual reality of EU security capabilities and employment has been skewed towards the softer end of the spectrum, which realists disdain and would not predict. This obviously applies to the maritime domain as well, where EU capabilities are more 'marine constabulary' in nature than anything else. The problem here is visible if we imagine a scenario 
where EU powers (France, Italy, UK, Spain, etc.) felt it necessary to urgently intervene in Europe's neighbourhood because of a NATO unwillingness or slowness to act. We should recall that during the Libyan crisis of 2011 , the Obama administration was reluctant to initially use force. Germany refused to participate in the NATO mission but did not block it. Turkey, within NATO, has distinctive interests that may, in the future, make a NATO operation problematic or delayed, as has happened in the past concerning Macedonia, where Greek and Turkish objections delayed the transition from a NATO peace-keeping mission to an EU one (Phillips 2004: 181). Turkey was also initially very lukewarm about NATO's 2011 military intervention in Libya.

In the event that EU naval forces have to be rushed into some kind of more-demanding action, the EU maritime security strategy would appear gloriously irrelevant, as it is basically a worthy 'laundry list' of 'soft security' challenges and capabilities in a scenario that would demand hard security assets. The EU Battle groups would seem hardly up to such a task (one might debate this). EUNAVFOR would provide only a limited template for what would have to be an aggressive amphibious operation of scale. The last time the French and British tried something like this on their own was at Suez in 1956. Perhaps, realists might predict that over time EU maritime security will evolve such 'harder' 'insurance' capabilities or else risk irrelevance in the marketplace for institutional security regimes.

In contrast, the liberal school of IR theorists would not be surprised that the EU has not developed 'hard' maritime security. For them, 'normative power Europe' has simply gone to sea. The MSS of 2014 has thus taken the rather typical medley of liberal security conceptions and translated them to marine and naval settings. However, the puzzle here is the disconnect. This signifies, from more material, EU maritime interests and the utility of force to uphold international norms in extreme cases, notably the controversial 'right to protect' doctrine.

By making such an emphasis on upholding the rule of international law as the primary objective of it's own maritime security strategy, the EU sets rather obvious snares for itself if the regime of international law is actually quite complex and contested or given to manipulation by great powers who do not share European interpretations. 
To cite an example already mentioned, the UN authorization for an EU maritime mission (Operation Sophia) off the coast of Libya (Resolution 2240) took a very long time to emerge because of Chinese and especially Russian opposition in the Security Council. It is well known that this originates from unease about the way the original UN mandate to intervene in Libya in 2011 was permissively interpreted by the western powers/NATO, to justify arming rebel groups and, eventually, regime change. In the end, a mandate was grudgingly approved but in a way that actually limited the EU's Operation Sophia to outside Libya territorial waters. $15 \mathrm{Had}$ it not been forthcoming, the EU would have had to contemplate a unilateral intervention without a UN mandate. The legality of such use of force would be, a priori, questionable and thus in conflict with the EU's stated adherence to the rule of international law.

Such scenarios reveal the EU has material and territorial interests in marine security that may conflict with the rule-of-law norms that the EU preaches, and central to that problem is also a fundamental evasiveness over the use of force in the EU's MSS. As has been explained, the MSS text does not make very clear how, when, and where the EU will actually fight to get what it wants regarding EU maritime security. Admittedly, the document does not state that EU marine security operations will be contingent on UN mandates, but the references to international law and regimes are so extensive that they would make any unilateral European action at sea seem an obvious contradiction with the logic of 'normative power' Europe.

Another interpretation is that unilateral military interventions in such scenarios, if they were truly needed (say, because no lawful alternative could be found), would be simply left to other actors. The EU, as a liberal normative security regime, would then stand down, as rougher elements (NATO or a coalition of the willing) would turn up to fight with or without UN mandates if need be. In some ways, this means the EU maritime security regime has painted itself into a corner, in contrast to the assertion in much of the literature on liberal normative IR approaches, which stresses the imperialistic ambitions of the approach to expand and be widely applied (Doyle 1986; Schimmelfennig 2001). 


\section{A Neo-Medieval Perspective on the EU and the EUMSS}

How then are we to make sense of these puzzles? This paper offers the 'neo-medieval' perspective as an alternative IR tradition that can make sense of the EU's puzzling foray into maritime security, especially of the 'softer' style it seems mostly, for now, to encompass. Central to this is the bold claim that the EU might best be understood as a 'neo-medieval Empire' in contrast to academic views, which hold the EU to the standard of being something like a Westphalian state actor, or on the way to being such. This body of work is today most clearly associated with the writings of Jan Zielonka (2006), however, its antecedence is usually traced back to some comments made by Hedley Bull in his 'Anarchical Society' (1977), where he imagined in the future: 'sovereign states might disappear and be replaced not by a world government but by a modern and secular equivalent of the kind of universal political organisation that existed in Western Christendom in the Middle Ages. In that system no ruler or state was sovereign in the sense of being supreme over a given territory and a given segment of the Christian population...' (Bull 1977: 254).

It is important to point out that Bull only sketched out the neo-medieval idea as metaphor, which is how it is used to explain the complexity of the EU today. He did not in fact think states had yet lost their sovereignty to the extent that a genuine neo-medieval order was really upon us. This is important, because a neo-medieval perspective does not have to involve the claim that nation states do not continue to matter, when they clearly do. Not much would happen regarding EU naval or maritime security efforts without the French, Germans, and the British nation states, but it is surely not reducible to their bargaining and interests alone. Moreover, strong national maritime interests and institutions, despite rumours of their demise, remain coherent and highly capable actors. Instead, the central claim, as Zielonka puts it, is that the EU is unlikely to become itself a cohesive federal Westphalian state, principally because of the absence of common demos. The result is a polity that partly builds on existing nation states but also goes well beyond this and in ways that are confusing.

Rennger (2006) adds another dimension of the invocation of neomedievalism by suggesting that while a de-centring of political authority is the central phenomenon of note, this 'new world' will also be post- 
modern and, therefore, replete with ethical and normative conflict in the absence of shared ethical meta-narratives (Rennger 2006: 64-66). Foreign policy-makers will have their post-modern work cut out for them, pitching justifications and legitimacy to such a diverse 'audience'. So while there may be a broad consensus on a mix of democracy, markets, and rule of law within the EU polity, there may not be much else by way of shared values. The implications of this are not immediately obvious for the EU's marine security strategy, but it means that agreement on the 'wrongs and rights' of what that policy is supposed to address may be elusive. Certain issues (piracy) may enjoy broad disdain, but other topics may be more divisive, for example, whether boat people should be seen as a 'threat to borders' or 'victims to be saved at all costs'.

It is worth clarifying the neo-medieval perspective a little before we attempt to extract implications from it for the EU's maritime security policy. First, we can dispose of some misconceptions. There is no literal claim that the EU has become a new Holy Roman Empire, or that it actually is a replay of medieval political pathologies. Instead, the point is there are functional analogies between the medieval system and the polity the EU has become today. For example, the borders of the EU are somewhat unclear, just like many borders were in medieval times, although not exactly in the same way.

Some EU states keep pretty 'hard', rigidly policed borders (as we are seeing in the case of Hungary), but these are being challenged, contested, and negotiated from below (by people movements) and above (by the EU itself, as we see being played out in Hungary). Moreover, what polity is 'in' and what polity is 'out' of the wider spheres of influence of the EU is vague and shifts. Accession agreements are signed, but progress and entry is far from automatic. Croatia was left waiting for 10 years in a limbo-like pre-accession status before being permitted to become a full member. The entire Western Balkans is a question mark as to what extent all, or just some, of the various states there will join the EU, or when they will do so: 10 years or 20 years from now? Equally, Brexit puts the stability of the EU's western borders in question, for example, raising issues of Scottish and, perhaps, Catalan independence.

As we have seen before, those countries that actually participate in EU policies and hold to EU norms are much wider than the list of member 
states. In EUNAVFOR, Norway was a significant and valuable presence, as she is the FRONTEX missions today, although she is not at all an EU member state and looks most unlikely to become one anytime soon. Yet her participation is so extensive in EU affairs that Norway is routinely described as a 'stealth' member state. Small but politically significant contributions were made by other non-member states. This type of 'fuzziness' is so ubiquitous as to be a 'norm'.

Moreover, according to Zielonka, there is likely to be considerable flux about EU borders in a way that echoes medieval practices of suzerainty. Turkey was 10 years ago considered to be on a progressive track for membership. However, that pathway was until recently stalled, and only in 2015 was it resuscitated. Whether the $\mathrm{EU}$ is or is not committed to anything more than association, status for the Ukraine and Moldova remains vague. Such opacity about the limes of the EU's empire constitutes a reality that justifies the sobriquet 'neo-medieval'.

Another confusion concerns whether the neo-medieval analogy implies anarchy, chaos, or to what extent such an order would be stable. While Bull clearly implied that the decline of states would produce a certain amount of chaos before a new order was reconstituted, the wider neomedieval literature is careful not to suggest that a neo-medieval polity is chaotic, internally disordered, or incapable of patterns of coercion on 'subjects' and constituent polities. The medieval realm, after all, had strong forces that imposed some cohesiveness. The 'unity of Christendom', as historian Maurice Keen used to style it, was one normative force (Keen 1991). Today it has been suggested that wide consensus on some form of regulated market capitalism, together with liberal democracy, the rule of law, and respect for human rights provide a secular equivalent (Friedrichs 2001).

However, it would be very wrong to infer that a neo-medieval polity such as the EU is conversely always a settled project. Collapse and breakup are possible outcomes (Zielonka 2014). For one thing, the EU's boundaries and extent are, as we have seen, somewhat unclear. I think an important part of the neo-medieval description of the $\mathrm{EU}$ is that its future trajectory is not settled. Membership is fluid. The Union's borders to the east and in the Mediterranean are liable to shift and be contested. The EU will, like 
all empires, display ambitions to expand its extent, influence, and power. There will also be countervailing internal forces, voices, and interests who seek to reign in ambition and return the EU to a smaller project, less imperial, more territorially cohesive, less complex, costly, and risky. Both impulses will to and fro, and we should expect such dynamics to play out in discrete domains, such as EU maritime security policy.

It should also be clear, after the annexation of Crimea in 2014, that the expansion of the EU will be externally contested by other imperial powers, using a mix of hard and soft power. China has threatened to ground EU aircraft and cancel Airbus orders when the EU attempted extra-territorial regulation of aircraft emissions trading. Russia has deployed naval and air assets menacingly in rather traditional Cold war ways, a move that NATO rather than the EU has seen fit to respond to through a policy of 'military confidence building'. NATO has also staged elaborate BALTOPS exercises in 2015 and 2016, to reassure the very nervous Baltic States. These have included aggressive scenarios that envisage amphibious landings to counter a Russian occupation. The EU's maritime security strategy here is ominously silent. Moreover, its relevance to such hard security threats is seemingly minimal.

\section{Conclusion: Implications from the Neo-Medieval Perspective for EU Maritime Security}

To extract possible implications from the neo-medieval perspective, we can utilize two essays by Jan Zielonka $(2011,2013)$, where he considers the EU as an actor in the international system. First, he observes that the polycentric nature of EU decision-making means that the EU finds it difficult to articulate and execute a unified common policy unless over valence issues ${ }^{16}$, which command wide support (2011: 289). Piracy at sea is obviously such a valence topic. Who could not be against it? What other maritime security problem could draw in the Chinese, Asian, European, the US, and even Russian navies, all to work together off Somalia? Seen

16 Best defined as: "Valence issues in their simplest sense are those for which there is really only one side - for example peace, prosperity, ...everyone is on the same side" (Maddox and Lilie 1984: 135). 
this way, EUNAVFOR's success is not so remarkable, and we can suggest if the issue was one not given to consensus (say, a second intervention into Libya) then the EU would find it much harder to agree to deploy and execute a more-controversial maritime security mission.

Second, the EU is mostly a civilian power, which does not mean she has no military means but rather that using such is (a) not the preferred option, and (b) because the EU's military power is shallow and brittle, it has to be used selectively, otherwise it will very likely fail, which generates important feedback de-legitimising the EU. Zielonka's core insight here is that the EU's 'hard' military power is essentially limited, even if an impressive plethora of peace-keeping and constabulary-like missions have been undertaken, such as EUNAVFOR. The result is an EU polity with 'ace cards', at best, being the hard economic instruments of trade deals and market access. This makes the EU likely to back down when faced with a serious military challenge. Instead the reflex is to use the EU's economic power instead. We see as much over the evolving EU row over the extent, severity, and possible relaxation of sanctions against Putin's role in the ongoing Ukraine crisis.

However, these features should logically make the EU a discriminating actor that would want to choose when, where, and how to deploy force at sea with some care. It has to, because it has to husband what limited maritime capabilities it has. Any mistakes could be fatal for the stability of what is a new and still-unproven security regime. This insight suggests we should predict caution rather than boldness from the EU maritime security regime. This partly explains why we had to wait till EUNAVFOR in 2008 for the major debut of a distinctively EU-branded maritime operation, and why Operation Sophia has evolved tentatively, despite some ambitious staff planning that imagined something much more robust.

Related to this, what we would not expect is that the EU will lurch towards developing hard naval power to balance its soft normative side, as realists suppose. Instead, what is of more interest is how the EU MSS seems 'doomed' to skirt the 'grey zone' of intermediate levels of force. In this respect, one could be optimistic that the EU might offer a niche of capabilities to engage in less-lethal and more-nuanced forms of force at sea. This is something that NATO can do, but it may sap and undermine NATO's focus on intensive war-fighting roles at sea. I have previously 
argued that NATO and the EU should consider a functional division of labour, whereby the EU deliberately should develop its soft maritime security capabilities and leave proper naval defence roles to NATO or the national level (Flynn 2015). Alex Calvo (2014), for example, has written on the need for intermediate-level maritime forces, noting how in the South Pacific increasing tensions between China and Japan are played out by judicious use of coastguard-type forces rather than navies. These employ less-lethal tactics and, in post-modern style, share the sea with nationalist activists, 'rent-a-mob' fishermen and various other non-state actors (Liss 2013). Who better to face down post-modern threats at sea than a postmodern polity such as the EU?

Third, regarding borders and centre-periphery relations, the EU, unlike other possible 'imperial powers' (America, China, Russia), is faced with a very dynamic and fluid situation. There are many states on the periphery that are associates of the EU, or as Zielonka styles them - 'protectorates'. The Balkan countries are obvious examples here, but also some Africa states, such as Tunisia and perhaps eventually Libya. One implication of this, for any EU maritime strategy, is that the emphasis on global operations in the CRIMSON projects and in the MSS text will be in tension with the need to provide proximate marine stabilisation forces for the EU's near waters. Zielonka describes this tension as a proclivity to be more inward looking rather than externally focused (2013: 12).

It is all very well to help local navies keep the straits of Malacca free from piracy, so that Europe's trade with China and South East Asia can prosper. However, if at the same time the Mediterranean faces an unprecedented human security emergency, then clearly the EU's maritime security policy has to make some hard but obvious geopolitical choices about where it will devote its attentions and capabilities. Consider that the Italian Navy and Coastguard, augmented by ships from other countries, were rescuing around 9,000 people a week and, in some 24-hour periods, thousands of people during 2015 (Patalano 2015: 17). That magnitude of a problem requires the EU's MSS to either step up and become involved or risk being seen as irrelevant. We can see this geopolitical tension playing out already. As ships and assets are pooled to help FRONTEX deal with the humanitarian disaster unfolding in the Mediterranean, does this mean EU states will want to pull their vessels from EUNAVFOR and an anti-piracy 
mission that seems to have run its course? It will be interesting to see what happens when the mandate for EUNAVFOR is reconsidered in late 2016, but arguably there will be a growing logic to have EU naval capabilities pitched closer to home, especially given the fuzzy and contested maritime borders of the EU imperium.

Zielonka also points to the fundamental weakness of the EU as neomedieval polity to pressures from other great powers (America, Russia, and China) that can easily exploit the EU's diversity and polycentric decisionmaking (Zielonka 2013: 12). Thus, we should expect quite a bit of regime competition between, say NATO and the EU's MSS, which so far has been a pragmatic relationship, especially over anti-piracy. Yet how quickly we forget that during the Bush presidencies (2000-2008), the desire for some Europeans to have distinct security capabilities apart from American military hegemony was attractive. It is not impossible that future American presidential administrations, or events in the Pacific concerning China, might conspire to push European states towards looking increasingly to themselves for security and defence capabilities. This would in theory make an EU maritime security policy much stronger, more ambitious, and likely have a great focus on the harder 'naval defence' aspects. However, it is also as plausible that European states would be divided. Would some states choose to follow American global leadership, including even a major naval confrontation in the Pacific with China? Post-Brexit Britain would seem an obvious candidate here. Would other EU states, such as Germany, refuse to simply get involved? We cannot know for sure, however, Zielonka's observation here is that the EU as quasi-empire is relatively easy to divide. Moreover, the other great powers, notably the USA, have considerable say in how the EU evolves by their own actions.

Finally, because so much emphasis has been placed on soft instruments and normative power, the EU will have to be careful to ensure its normative credentials are as impressive as it likes to claim. A huge test of that is arguably happening now regarding the boat people tragedy, which has unfolded in the wider Mediterranean (including as far as the Canary Islands in the Atlantic). The Italian solution in Operation Alba (1997) is no longer available. Mounting a de facto blockade and turning back refugees is not legally permissible anymore. In 2012, the ECHR in its Hirsi 
ruling ${ }^{17}$ found heavily against the Italian state for intercepting and returning boat people to Libya in 2009 (at least one of these subsequently died in Gaddafi-era camps). Moreover, the seas are not left to Coastguards and navies alone in this unfolding disaster. One novelty of the current situation is the presence of private NGO actors at sea: Médecins Sans Frontières (MSF) have no less than three ships together with MOAS (Migrant Offshore Aid Station), a charitable organisation that features several highly experienced ex-military personnel. ${ }^{18}$ We might also speculate here that the EU, as a neo-medieval polity, could be more comfortable resorting to private commercial marine security actors more than the nation states, whose Navies and Coastguards are not keen to be done out of 'business'. This is less a question of private navies and security contractors at sea, but more likely the less-controversial providers of drones, imagery, logistics, and other types of support. This trend is already evident for land operations, and the neo-medieval approach would expect it to grow in the maritime domain as well (Gould 2015; White and Macleod 2008).

Overall, the normative environment the EU faces is arguably more complex than ever, post-modern in style, and certainly not one that will be dominated by Europeans alone. It is very possible that growing Chinese, Brazilian, and Indian voices within UNCLOS epistemic communities might seek to change key features of that basic legal framework for the sea. They may seek, for example, to reduce the scope for 'innocent passage of warships' or make EEZs into something more like territorial seas or change the definition of artificial Islands. Europe might be quite alone in such fraught negotiations, given America's formal absence from the UNCLOS framework.

In conclusion, the neo-Medieval framework helps bring a large dose of reality to the EU's MSS and serves as a useful corrective for what has been a rush to infer so much from just one very successful mission: operation Atalanta. Given that the EU as a polity remains widely viewed as ambiguous, confusing, and contingent in its stability and direction, should we not expect the same from the EU's maritime security policy?

17 See: Hirsi Jamaa and Others v. Italy (Application no. 27765/09), Judgment delivered 23 February 2012.

18 See: http://www.moas.eu/. The ex-military personnel are notably from the Maltese armed forces. Vessels include the Phoenix, which has been operational off the coast off Libya since May 2, 2015, replete with a leased drone. This vessel has been joined by a second boat, the Bourbon Argos, which has a rescue capacity of 700 people, and there is a third vessel, Dignity 1. 


\section{Bibliography}

Arnold, G., 2015. Street-level policy entrepreneurship. Public Management Review, 17 (3): 307-327.

Bailes, A. JK and Messervy-Whiting, G., 2011. Death of an institution: the end for Western European Union, a future for European defence? Egmont Paper, 46.

Bueger, C., 2015. "What is maritime security?" Marine Policy, 53: 159-164.

Bull, H., 1977. The Anarchical Society. London: MacMillan.

Calvo, A., 2014. Small Wars and Non-Lethal Force at Sea: The Wave of the Future? Small Wars Journal, July 17th, available at: http:// smallwarsjournal.com/jrnl/art/small-wars-and-non-lethal-force-atsea-the-wave-of-the-future

Catalano, C., 2015. The Untold story: the Italian role in the development of a European Defence, In Marchi, L., Whitman, R.,Edwards, G. Italy's Foreign Policy in the Twenty-first Century: A Contested Nature? London: Routledge. pp. 88-95.

Council Of The European Union., 2014. European Union Maritime Security Strategy as Adopted by the Council (General Affairs) on 24 June 2014, Brussels, 24 June 2014 (OR. en), 11205/14. Available at: http:// register.consilium.europa.eu/doc/srv? l=EN\&f=ST\%2011205\%20 $2014 \% 20 I N I T$.

David, C. P., 2015. Policy Entrepreneurs and the Reorientation of National Security Policy under the G. W. Bush Administration (2001-04), Politics \& Policy, 43(1): 163-195.

Dijkstra, H., 2009. Commission versus Council Secretariat: an analysis of bureaucratic rivalry in European foreign policy." European foreign affairs review, 14 (3): 431-450.

Doyle, M. W., 1986. Liberalism and world politics. American Political Science Review, 80 (4): 1151-1169.

Flynn, B., 2015. Counter Piracy Today: how essential is a mission for both 
NATO and the EU? , Atlantic Voices, 5 (8): 1 1-15. Available at: http:// www.slideshare.net/Atlantictreatyassociation/atlantic-voicesmaritime-security.

Friedrichs, J., 2001. The meaning of new medievalism. European Journal of International Relations, 7 (4): 475-501.

Gebhard, C. and Smith, S.J., 2014. The two faces of EU-NATO cooperation: Counter-piracy operations off the Somali coast. Cooperation and Conflict, 50(1): 107-127.

Germond, B., 2015a. The Maritime Dimension of European Security: Seapower and the European Union. Palgrave Macmillan.

Germond, B., 2015b. The geopolitical dimension of maritime security. Marine Policy. 54: 137-142.

Germond, B., and Smith, M.E., 2009. Re-Thinking European Security Interests and the ESDP: Explaining the EU's Anti-Piracy Operation, Contemporary Security Policy, 30(3): 573-593.

Gould, A., 2015. Global assemblages and counter-piracy: public and private in maritime policing, Policing and Society, forthcoming.

Gray, Colin S., 201 1. Hard Power and Soft Power: The utility of military force as an instrument of policy in the 21 st century. Strategic Studies Institute. Available at: http://www.strategicstudiesinstitute.army. mil/pdffiles/PUB1059.pdf.

Hilsman, R., 1987. The politics of policy making in defense and foreign affairs: conceptual models and bureaucratic politics. Englewood Cliffs, N.J.: Prentice-Hall.

HM Government (UK)., 2014. The UK National Strategy for Maritime Security. May 2014. Available at: https://www.gov.uk/government/uploads/ system/uploads/attachment_data/file/310323/National_Strategy_ for_Maritime_Security_2014.pdf.

House of Lords/European Union Committee., 2012. 31st Report of Session 2010-12: European Defence Capabilities: lessons from the past, signpost for the future. HL Paper 292. Available at: http://www.publications.parliament.uk/pa/ld201012/ldselect/ Ideucom/292/292.pdf. 
Kaunert, C., and Zwolski. K., 2014. Somalia Versus Captain 'Hook': Assessing the EU's Security Actorness in Countering Piracy Off the Horn of Africa. Cambridge Review of International Affairs, 27(3): 593-612.

Keen, M., 1991. The Penguin History of Medieval Europe. London: Penguin. Kluth, M. F. and Pilegaard, J., 2011. Balancing beyond the horizon? Explaining aggregate EU naval military capability changes in a neo-realist perspective, European Security, 20 (1): 45-64.

Lindley-French, J., 2004. The revolution in security affairs: hard and soft security dynamics in the 21 st century." European security, 13 (1-2): $1-15$.

Liss, C., 2013. New Actors and the State: Addressing Maritime Security Threats in Southeast Asia. Contemporary Southeast Asia: A Journal of International and Strategic Affairs, 35 (2): 141-162.

Maddox, W. S. and Lilie, S.A., 1984. Beyond Liberal and Conservative: Reassessing the Political Spectrum. Washington, D.C.: Cato.

Marquina, A., 1998. Spanish foreign and security policy in the Mediterranean, Mediterranean Historical Review, 13:1-2, 235-247.

Marta, L., 2008. The UNIFIL II Mission in Lebanon: Italy's Contribution. Real Instituto Elcano Papers. Available at http://www. realinstitutoelcano. org/wps/portal/rielcano_eng/Content.

Patalano, A., 2015. Nightmare Nostrum? Not Quite: Lessons from the Italian Navy in the Mediterranean Migrant Crisis. The RUSI Journal, 160 (3): 14-19.

Perlmutter, T., 1998. The Politics of Proximity: The Italian Response to the Albanian Crisis. International Immigration Review, 32(1): 203-222.

Phillips, J. (2004) Macedonia: Warlords and Rebels in the Balkans. London: I.B. Tauris.

Rao, P. V., 2010. Indian Ocean maritime security cooperation: the employment of navies and other maritime forces. Journal of the Indian Ocean Region, 6 (1): 129-137.

Rennger, N. J., 2006. European communities in a neo-medieval global polity: the dilemmas of fairyland. In Kelstrup, M. and Williams, M. 
C., eds. International Relations Theory and the Politics of European Integration: Power, Security, and Community. London: Routledge. pp. 57-71.

Riddervold, M., 2011. Finally flexing its muscles? Atalanta - The European Union's naval military operation against piracy. European Security, 20 (3): 385-404.

Riddervold, M., 2014. New Threats - Different Response: EU and NATO and Somali Piracy. European Security. 23 (4): 546-564.

Riddervold, M., 2015. (Not) in the Hands of the Member States: How the European Commission Influences EU Security and Defence Policies. JCMS: Journal of Common Market Studies, forthcoming.

Rynning, S., 2011 . Realism and the Common Security and Defence Policy. Journal of Common Market Studies, 49 (1): 23-42.

Schimmelfennig, F., 2001. The community trap: Liberal norms, rhetorical action, and the Eastern enlargement of the European Union. International organization, 55 (1): 47-80.

Skeppström, E., Hull Wiklund, C. and Jonsson, M., 2015. European Union Training Missions: security sector reform or counter-insurgency by proxy? European Security, 24 (2): 353-367.

Tardy, T., 2014. CSDP: getting third states on board. European Union Institute for Security Studies Brief 6.

Trondal, J., Murdoch, Z. and Geys. B., 2015. On Trojan Horses and revolving doors: Assessing the autonomy of national officials in the European Commission. European Journal of Political Research, 54 (2): 249-270.

Vanhoonacker, S., Hylke D., and Maurer, H., 2010. Understanding the role of bureaucracy in the European security and defence policy. EIOP. Available at: http://eiop.or.at/eiop/index.php/eiop/issue/view/24.

White, N. D., and MacLeod, S. 2008. EU operations and private military contractors: issues of corporate and institutional responsibility. European Journal of International Law, 19 (5): 965-988.

Whitman, R. G. and Wolff, S., 2012. The European Union as a global Conflict Manager: capabilities and context in an interdependent world. In 
Whitman, R. G. and Wolff, S., eds. The European Union as a Global Conflict Manager. Oxfordshire: Routledge. pp 3-19.

Wollert, C., 2013. Naval Assets: not just a tool for war. In Engelbrekt,K., Mohlin, M., Wagnsson, C., eds. The NATO Intervention in Libya: Lessons Learned from the Campaign. London: Routledge. pp.128-149.

Zielonka, J., 2006. Europe as Empire: The Nature of the Enlarged European Union. OUP, Oxford.

Zielonka, J., 2011. The EU as an International Actor: Unique or Ordinary? European Foreign Affairs Review, 16, 281-301.

Zielonka, J., 2013. The International System in Europe: Westphalian Anarchy or Medieval Chaos? Journal of European Integration, 35 (1): 1-18.

Zielonka, J., 2014. Is the EU Doomed? London: John Wiley \& Sons.

Brendan Flynn has been a lecturer within the School of Political Science \& Sociology, NUIG, since 1998. He has studied at the University of Essex for his Masters and PhD degrees, the latter on: "Subsidiarity and the Evolution of EU environmental policy". He teaches European and marine policy and politics while his research is focused on marine renewables and EU marine security debates. His most recent major research project has been the Irish Fishers' Knowledge Project (2008-2013). 